\title{
Sikap Hukum Islam terhadap Tindakan Terorisme
}

\section{Rohidin}

\begin{abstract}
Islam is very untolerable the violence in any form and any purpose. Although, Islam in certain condition, the apply of violence is permissible but it must be taken on the law corridor. It means that the violence could be applied along with meeting the requirements, like the law sanction of violence, where such law sanction appear of expressing on antiviolence in Islam.
\end{abstract}

\section{Pendahuluan}

Terorisme adalah sebutan untuk kelompok atau golongan tertentu pelaku teror. Sedang kata teror secara etimologis berasal dari bahasa latin terrere yang berarti "menyebabkan ketakutan." Secara Terminologis kata ini diberi pengertian sebagai "tindakan yang dilakukan oleh manusia atau kelompok secara sengaja yang bertujuan untuk mempengaruhi atau mengintimidasi seseorang atau kelompok lain agar yang bersangkutan merasa tidak aman, tidak nyaman dan berakhir dengan penghancuran fisik maupun non fisik."2 Sedangkan Richard Falk mendefinisikan "terorisme" dengan "setiap tindakan kekerasan politik yang tidak memiliki justifikasi moral dan hukum, apakah tindakan kekerasan itu dilakukan oleh suatu kelompok revolusioneí atau pemerintah atau negara. Tetapi terdapat perbedaan di antara berbagai kalangan ahli dan pemerintahan tentang kekerasan politik (polifical violence) yang justifiable dan unjustifiable, tergantung pada siapa yang menilainya. Kekerasan politik yang "unjustifiable" bagi sebagian orang atau kelompok sangat boleh jadi "justifiable" bagi pihak lainnya. ${ }^{3}$

Dalam sejarah, kata ini sebenarnya sudah lazim digunakan dalam pengertian politis sebagai serangan terhadap tatanan sinil pada akhir abad XVIII.

\footnotetext{
'Mark Juergens Meyer, Teror Atas Nama Tuhan Kebangkitan Global Kekerasan Agama, Terj. M. Sadat ismail (cet. 1), (Jakarta: Mizan Press, 2002), him. 5.

2Eusta Supono,"Terorisme" calam harian Bemas, Kamis 17 Oktober 2002, hlm. 2.

${ }^{3}$ Lihat Azyumardi Azra dalam http://mail2.factsoft.de/pipermail/national/2002 November/010752./.html $30-$ 10-2003/10:6 WIB
} 
Belakangan, istilah terorisme kembali mengemuka sebagai wacana internasional terutama dengan dimotori oleh Amerika Serikat setelah terjadi tragedi runtuhnya gedung WTC. Karena tuduhan Amerika Serikat dialamatkan pada sekelompok orang yang kebetulan beragama Islam dan berasal dari wilayah yang menyebut dirinya sebagai negara Islam, maka Amerika dan sekutunya kemudian disamping melancarkan serangan fisik terhadap negaranegara Islam tertentu, juga menebarkan secara sistematis virus terorisme keberbagai belahan dunia terutama wilayah-wilayah atau negara dimana terdapat kelompok Islam tertentu tidak terkecuali Indonesia sebagai negara dengan penduduk muslim terbesar.

Respon atas virus yang ditebarkan Amerika di Indonesia muncul dalam bentuk-bentuk semacam rumusan rancangan peraturan perundangan baik berupa Perpu maupun Undang-undang tentang pemberantasan tindak pidana terorisme. Apalagi di Indonesia sendiri juga terdapat serangkaian peristiwa pengeboman yang kemudian diidentifikasi sebagai tindak pidana teror dan kebetulan juga pelakunya berasal dari kultur Islam. Akibatnya semakin kuatlah tekad pemerintah untuk merespon "pesan" dari pihak luar yakni produk hukum tentang pidana khusus ini.

Meskipun tindak pidana ini bisa dilakukan oleh siapa saja di luar Islam baik oleh lembagalembaga besar seperti negara maupun kelompok-kelompok organisasi yang lebih kecil seperti kelompok-kelompok keagamaan tertentu dalam Yahudi, Kristen maupun Hindu, akan tetapi tidak bisa disangkal bahwa istilah ini tampak sekali berkonotasikan Islam. Akibat dari beberapa peristiwa teror belakangan ini adalah terbentuknya opini masyarakat bahwa Islam adalah agama kekerasan. Islam adalah agama yang disiarkan dengan pedang. Seakan Islamlah satu-satunya yang bertanggungjawab atas setiap aksi teror.

Padahal seperti yang tercermin dari kata yang digunakan untuk nama agama ini dalam bentuk turunannya yang bagaimanapun tetap bermuara pada pengertian tentang "selamat dan damai". Kata Islam sama sekali jauh dari konotasi kekerasan. Apalagi sebagai sebuah ajaran agama samawi terakhir, Islam menjadi sebuah sistem yang konprehensif, yang terkandung di dalamnya sistem keyakinan, ritual, moral dan juga hukum. Isiam juga telah dilengkapi dengan berbagai perangkat dan cabang-cabang hukumnya yang meliputi hukum privat dan publik dengan segala macam klasifikasi hukumnya.

Persoalannya sekarang adalah bagaimana hukum Islam itu sendiri melihat kejahatan teror, suatu tindak kejahatan yang kerap kali dituduhkan pada Islam. Tulisan ini akan mencoba menelusuri jawaban atas pertanyaan tersebut dengan cara mengenai karakter dari setiap peristiwa yang diidentifikasi sebagai tindak pidana teror kemudian dihadapkan dengan berbagai ketentuan dalam hukum pidana Islam.

\section{Teror di Berbagai Belahan Dunia}

Sebagaimana disebutkan di muka, bahwa sebenarnya istilah teror sudah dikenal orang sejak beberapa abad silam. Namum kemudian peristiwa ini nampak semakin marak dipenghujung abad $X X$ dan titik-titik awal abad XXI diberbagai belahan dunia dan juga di Indonesia. Sejarah aksi kekerasan ini telah mencatat bahwa pelaku dari berbagai aksi kekerasan ini dapat berasal dari kelompok keagamaan manapun dan dengan modus 
yang beragam pula. Pada tahun-tahun antara 1984 hingga 1999 aksi pengeboman dan pembakaran klinik-klinik yang biasa digunakan untuk praktek aborsi, dilakukan oleh komunitas kristen di Amerika bahkan sebagian pelakunya adalah pimpinan gereja semacam pendeta Rev. Michael Bray dari Bowie Maryland. Pada tahun yang sama dan dilakukan kelompok kristen juga, terjadi berbagai peristiwa seperti peledakan bangunan Olimpiade Atlanta, penghancuran bangunan Federal Oklahama City serta- penembakan sebuah pusat kesehatan Yahudi di California pada 10 Agustus 1999 oleh para aktifis Christian Identity. ${ }^{4}$ Walau para pelaku dari kalangan kristen ini tidak mengakui bahwa itu adalah tindak terorisme bahkan mereka mengklaim sebagai tindakan ibadah dalam rangka membrantas penyelewengan moral, tetapi tetap saja apa yang mereka lakukan mengakibatkan hancurnya bangunan fisik bernilai tinggi serta hilangnya banyak nyawa.

Pada tahun 1994 di Hebran Palestina juga terjadi pembantaian warga muslim melalui 111 tembakan oleh seorang tokoh Yahudi Goldstein. ${ }^{5}$ Meskipun di mata orang-orang Yahudi Goldstein adalah seorang patriot dan tindakannya adalah sesuatu yang benar menurut teologi mereka tetapi lebih dari tiga puluh jiwa orang Islam yang sedang melaksanakan ibadah shalat subuh, melayang dalam tempo yang sangat singkat. Korban dari warga sipil dan rasa takut yang ditebarkan oleh tindakan Goldstein di kalangan muslim Arab adalah ciri krusial dari tindak pidana terorisme.

Berbagai organisasi kekuatan Hindu dan Sikh di India juga merupakan bagian yang tidak terpisahkan dari tindak pidana terorisme dalam skala Internasional. Pada tahun 1984 misalnya, lebih dari 2000 orang dibantai di sebuah kuil Sikh. Kematian orang-orang Sikh beserta pimpinannya (Bhidranwale) dan penodaan terhadap kuil suci mereka melalui serangkaian tembakan telah memicu ketakutan dan kemarahan di kalangan Sikh yang puncaknya adalah pembunuhan nyonya Gandhi sebagai balas dendam dari kelompok Sikh. Tindak selanjutnya yang memakan korban lebih dari 2000 lagi orang Sikh di Delhi, ${ }^{5}$ adalah tindak kekerasan dari kelompok Hindu yang sangat menakutkan.

Di kalangan muslim, terlepas dari adanya sejumlah fakta yang bisa dijadikan alasan pembenar bagi tindakan mereka, memang muncul. kelompok-kelompok tertentu yang akrab dengan tindakan kekerasan yang sama. Usaha peledakan garasi parkir World Trade Center New York di tahun 1993, pengeboman pangkalan militer Amerika di Dhahran Arab Saudi pada tahun 1996 atau pengeboman kedutaan besar Amerika di Kenya dan Tanzania pada Agustus $1998^{7}$ adalah beberapa contoh peristiwa tindak kekerasan yang pelakunya ditengarai dari lingkungan muslim, termasuk di dalamnya misi bunuh diri dari kelompok aktifis muslim Palestina di

${ }^{4}$ Mark Juergens Meyer, Op. Cit., hlm. 24. Lihat htto://www.irib.ir/worldservice/melayuRadio/perspektiff islam terorisme/htm/30-10-2003/10:15 WIB.

${ }^{5} \mathrm{lbid}, \mathrm{hlm} .65-66$.

Ibid, him. 128-129.

'Ibid, hlm. 79-80. 
Yerusalem dan Tel Aviv.

Bahkan di lingkungan agama Budha, sebuah agama besar dunia yang sulit terbayangkan muncul di dalamnya aksi kekerasan berbaju agama, juga ada yang punya andil dalam tindak pidana terorisme. Pada bulan Maret 1995 beberapa anggota dari Aun Shinrikyo salah satu cabang agama Budha di Jepang menggunakan gas beracun untuk membunuh sejumlah penumpang kereta api bawah tanah serta melukai ribuan penumpang lainnya. ${ }^{8}$

Peristiwa kekerasan tingkat dunia yang kemudian menjadi pangkal tolak terbentuknya opini publik tentang terorisme terutama yang ditujukan pada Islam adałah runtuhnya gedung World Trade Center di New York yang merupakan simbol kemegahan ekonomi Amerika serta gedung Pentagon di Washington DC sebagai simbol keadidayaan militer Amerika, pada September 2001. Total korban jiwa dari peristiwa terakhir ini diperkirakan mencapai 3000 orang $^{9}$ di samping korban material yang tidak temilai harganya.

Belum lagi berbagai peristiwa yang tejjadi di tanah air Indonesia ini. Sepanjang tahun 1998, 1999 hingga awal 2003 terjadi serangkaian tindak pengrusakan fisik dan pembantaian manusia atas berbagai tempat ibadah, plaza, restoran, hotel atau kantor-kantor bahkan rumah tempat tinggal. Terlepas dari masalah siapa pelaku dari semua tindak kekerasan ini, yang jelas bahwa hampir keseluruhannya memiliki karakter pengrusakan atas aset publik, penghilangan nyawa manusia terutama penduduk sipil, dan menebarkan suasana ketakutan di tengah masyarakat.

Jadi berdasarkan fakta yang ada dari setiap aksi terorisme dimanapun dan oleh siapapun dapat disimpulkan bahwa secara garis besar tindak kekerasan yang diidentifikasi sebagai tindak pidana terorisme memiliki tiga sifat dasar yaitu:

1. Pengrusakan massif aset publik baik properti, sumber daya alam ataupun pusat-pusat budaya.

2. Pembunuhan warga sipil yang tidak pernah dibenarkan oleh hukum baik dalam suasana perang apalagi suasana damai.

3. Menimbulkan ketakutan secara luas di masyarakat.

Ketiga sifat dasar dari tindak pidana terorisme di atas sebenranya dapat disebut sebagai ringkasan dari karakter tindak pidana terorisme dalam Pasal 6 Undang-undang tentang pemberantasan tindak pidana terorisme. ${ }^{10}$ Dalam pasal tersebut terkandung beberapa aspek yang bisa digunakan untuk membuat standard kriterium pengukur apakah sebuah tindakan dapat dikategorikan sebagai tindak pidana terorisme. Aspek-aspek tersebut antara lain:

1. Pelakunya adalah orang (dari manapun asalnya).

2. Sengaja menggunakan kekerasan.

3. Menimbulkan rasa takut secara luas.

4. Menimbulkan korban (jiwa maupun harta) secara masal.

\footnotetext{
8/bid, hlm. 133.

'Fuad Amsyari, "Kampanye Terorisme dan Reaksi Umat Islam," makalah Workshop, Yogyakarta, 2003, him. 1.

10Undang-undang No. 15 Tahun 2003 tentang Pemberantasan Tindak Pidana Terorisme, hlm. 7.
} 
5. Mengakibatkan kerusakan obyek-obyek vital, lingkungan hidup atau fasilitas publik. Tindak kejahatan yang memiliki kriteria tersebut di ataslah yang menurut undangundang Tidak Pidana Terorisme diancam dengan hukuman mati, penjara seumur hidup atau penjara paling ringan 4 (empat) tahun dan paling lama 20 (dua puluh) tahun.

Bagian berikut akan menghadapkan ketiga kriteria umum di atas dengan ketentuan hukum dalam islam. Namun untuk dapat dipahami secara nalar ketentuan hukum islam atas tindakan seperti ini, terlebih dahulu akan dipaparkan pinsip dasar ajaran Quran.

\section{Prinsip Etika Anti Kekerasan dalam Islam}

Islam adalah satu bentuk turunan kata dari akar al-silm yang mengandung pengertian pokok "damai", "selamat". Jadi Islam adalah gama perdamaian, cinta kasih jauh ari semangat kekerasan. Sementara ajaran Islam bersumber pada al-Quran dan al-Sunnah Nabi yang diredaksikan dalam apa yang disebut dengan al-Hadits. Dengan kata lain Islam adalah penjabaran dari prinsip-prinsip dasar al-Quran dan al-Hadits. Sementara alQuran tidak mengajarkan kekerasan dan kekerasan itu senidiri bukan bagian integral dari al-Quran. Jadi menciptakan perdamaian dan suasana damai adalah kewajiban agama bagi seorang yang menyatakan dirinya Islam (muslim).

Menurut al-Quran, muslim sejati adalah orang yang hidup dan matinya karena Allah dan demi menciptakan perdamaian. Sebegitu dalamnya semangat perdamaian dalam alQuran, sehingga bahkan memaki kepercayaan orang lainpun dilarang olehnya, apalagi berbuat jahat dan memaksa dengan kekerasan pada pihak lain. Al-Quran menyatakan bahwa "janganlah kamu memaki sesembahan-sesembahan yang mereka sembah selain Allah, karena mereka nanti akan balik memaki Allah dengan melampaui batas tanpa pengetahuan." "Rendah hati dalam bertindak maupun bertutur kata telah diproklamirkan sedemikian rupa seperti dalam ungkapan-ungkapan al-Quran, "Dan hambahamba yang baik dari Tuhan Yang Maha Penyayang itu ialah orang-orang yang berjala? dimuka bumi dengan rendah hati dan apabila orang-orang jahil menyapa mereka, mereka mengucapkan kata-kata kedamaian. ${ }^{12}$ Dalam ayat lain dikatakan bahwa "Sederhanakanlah kamu dalam berjalan dan lunakanlah suaramu, sesungguhnya seburuk-buruk suara adalah suara keledai. ${ }^{13}$

Semangat keadilan, berbuat baik, kasih sayang dan bijaksana adalah prinsip-prinsip dasar ajaran al-Quran yang harus menjadi muara dari setiap keputusan maupun tindakan. Artinya jika ada setiap keputusan atau pernyataan dan tindakan maka semua itu harus dikembalikan pada prinsip-prinsip di atas. Kalau sejalan dengan prinsip tersebut berarti diperbolehkan atau bahkan diar:jurkan dan sebaliknya jika bertentangan maka itu adalah larangan yang harus ditinggalkan atau kalau tidak ditinggalkan berarti ada resiko hukumnya.
"Q.S. 6:108.
${ }^{12}$ Q.S. 25:63.
${ }^{13}$ Q.S. 31:19. 
Dalam soal berbuat adil dan menciptakan keadilan, tidak sedikit al-Quran menyerukan untuk menegakan keadilan karena keadilanlah yang paling dekat dengan taqwa. Sebaliknya. al-Quran sangat menegaskan larangan untuk tidak berbuat adil apalagi ketidakadilan itu dilatarbelakangi oleh kebencian terhadap pihak-pihak tertentu. Adalah karena prinsip berbuat baik dan prinsip kasih sayang yang sedemikian dijunjung tinggi al-Quran, maka al-Quran berkali-kali melarang tindak pembunuhan kecuali ada alasan pembenarnya (hukum), juga melarang berbuat kerusakan di muka bumi beserta ancaman hukum bagi siapa saja yang bertindak demikian. Karena al-Quran menganggap lingkungan hidup dan makhluk hidup selain manusia sebagai makhluk dan umat yang sama dengan manusia, maka tindak pengrusakan dan pembunuhan atau kekerasan adalah larangan yang sangat tegas dalam al-Quran. Tantang ini al-Quran menyatakan "Tiadalah binatang-binatang yang ada di muka bumi dan burung-burung yang terbang dengan kedua sayapnya melainkan umat juga seperti kamu, ${ }^{14}$ "Dan berbuat baiklah sebagaimana Allah telah berbuat baik padamu dan janganlah berbuat kerusakan di muka bumi, karena sesungguhnya Allah tidàk suka orang-orang yang suka berbuat kerusakan. ${ }^{15}$
Larangan berbuat ruksak dimuka bumi daiam al-Quran disebut berkali-kali baik dengan larangan langsung (nahi darikata kerja afsada) maupun larangan tidak langsung. Ketidak sukaan Allah terhadap pembuat keruksakan ini di samping ditujukan dengan disediakannya siksa di akhirat kelak ${ }^{16}$ juga diancam hukuman langsung di dunia berupa hukuman mati. ${ }^{17}$

Prinsip kasih sayang juga dijunjung tinggi dalam ajaran Islam seperti yang tercermin dalam berbagai bentuk hadits Nabi SAW. Misalnya hadits riwayat Bukhori yang menyatakan "Cintailah manusia sebagaimana engkau mencintai dirimu sendiri", "Tidak akan masuk surga seseorang yang orang lain merasa tidak aman akibat ulahnya" Dalam hadits lain dinyatakan "Barang siapa tidak menyayangi sesama manusia maka ia tidak akan disayangi oleh Allah. ${ }^{18}$

Cinta kasih terhadap sesama, menurut hadits Nabi tidak saja disebutkan sebagai anjuran teoritis belaka tetapi juga pada tataran praksis atau terapan misalnya hadits yang diriwayatkan oleh Bukhari yang menyatakan "Berilah kemudahan pada orang lain, jangan mempersulit mereka dan berilah mereka kegembiraan jangan buat mereka lari karena ketakutan". Karena menjunjung tinggi nilainilai cinta kasih pula maka Nabi mendefinisikan

${ }^{14}$ Q.S. 6:38.

${ }^{15}$ Q.S. 28:77.

${ }^{16}$ Q.S. 16:88.

${ }^{17}$ Q.S. 5:33.

${ }^{18}$ Salah satu hadis tersebut terdapat dalam At-Tajid al-sharih li al-ahadis halaman 7 yang disusun oleh Abi 'Abas Zaenudin Ahmad lbn Armad lbn Abd AJ-Latief dengan susunan riwayat sebagai berikut; diriwayatkan oleh Musadad dari Yahya dari Syu'aib dari Qatadah dan dari Shahabat Anas. Kualitas hadits ini shahih. 
orang muslim sebagai orang yang tidak mencelakakan orang lain baik dengan ucapan maupun tindakannya (H.R. BukhoriMuslim).

Bahkan ajaran tentang cinta kasih muncul tidak saja dalam larangan berbuat jahat pada orang lain tetapi juga dalam bentuk larangan mencelakai diri sendiri apalagi sampai membunuh dirinya sendiri. Banyak sekali hadits Nabi yang menggambarkan betapa berat siksa yang bakal diterima di akhirat oleh orang-orang yang nekad bunuh diri. Karena cara yang ditempuh bunuh diri di dunia ini akan diulang-ulang selamanya di akhirat kelak. Bagi yang bunuh diri dengan senjata maka dengan senjata yang sama dia akan melakukan bunuh diri di neraka secara terus-menerus. Demikian pula yang bunuh diri dengan cara-cara lain apapun akan disiksa dengan cara yang sama dengan yang dilakukannya di dunia ini. Karena itulah Nabi tidak mau menshalatkan jenazah orang bunuh diri. ${ }^{19}$

Dari uraian tentang ajaran-ajaran dasar dar al-Quran maupun al-Hadits seperti di atas, dapat diambil pengertian bahwa Islam adalah agama yang sama sekali jauh dari budaya kekerasan. Dengan kata lain Islam sangat tidak mentolelir tindak kekerasan apapun dan untuk tujuan apapun. Kalaupun Islam dalam kondisi tertentu membolehkan digunakannya suatu bentuk kekerasan, maka itu harus dilakukan dalam koridor hukum. Artinya tindak kekerasaan itu dapat dilakukan senanjang memenuhi syarat seperti daiam bentuk sanksi hukum atas tindak kekerasan, di mana sanksi hukum semacam ini muncul sebagai ekspresi anti kekerasan dalam Islam.

Jadi, harus dipahami dalam keranğka inilah -yakni dalam rangka menjunjung tinggi nilai kemanusiaan, cinta kasih dan keadailanbahwa dalam hukum pidana Islam dikenal adanya sanksi hukum yang berbentuk hukuman mati, hukum potong tangan atau hukum rajam. Dengan kata Jain, istilah-istilah jihad, qisas, rajam atau hukum potong tangar. bukan indikator bahwa Islam identik dengan tindak kekerasan, melainkan justru dalan rangka menghapuskan setiap bentuk kekerasan dan menegakan nilai-nilai kemanusiaan, perdamaian, keadilan dan cinta kasih sesama manusia. Dalam pengertian tertentu Islam adalah anti terhadap setia? tindak pidana teror yakni tindakaii destruktif dan merendahkan harga nyawa manusia.

\section{Terorisme Perspektif Hukum Islam}

Dalam hukum Islam, secara garis besar tindak pidana dapat dikelompokan menjadi dua kelompok besar sesuai dengan sifat sanksi hukumnya. Artinya menurut hukum Islam tindak pidana diklasifikasikan pertamatama berdasarkan sanksi hukumnya yakni sudah ditentukan secara definitif sanksi hukumnya oleh Allah apa belum. Karena itulah maka klasifikasi tindak pidana dalam hukum Islam menjadi Hadd dan Ta'zir sesuai dengan sanksi hukumnya.

Untuk tindak pidana yang dikenai sanksi hukum Hadd yakni tindak pidana yang dikenai sanksi hukum yang definitif disyariatkan oleh Allah, sudah jelas ketentuan hukumnya.

\footnotetext{
${ }^{19}$ Bernard Lewis, The Crisis of Islam, Holy war and in Holy Terror (New York: Modern Library, 2003), him.
} 154. 
Termasuk dalam tindak kejahatan type ini adalah kejahatan atas badan atau fisik (tubuh), jiwa atau organ tertentu. Maksudnya adalah tindak pidana pembunuhan atau sekedar mencedrai saja. Kedua adalah tindak kejahatan susila yakni yang lazim disebut dengan zina, prostitusi atau perkosaan. Ketiga, tindak pidana atas harta, dapat berbentuk penjarahan, pencurian dan ghasab. Keempat adalah tindak pidana yang menyangkut sikap mental misalnya tuduhan palsu dan minum khamar.

Untuk keempat jenis tindak pidana ini masing-masing sudah ditetapkan oleh Allah hukumannya, walaupun dalam eksekusi peran keluarga korban masih signifikan. Tindak pidana yang pertama diancam dengan dua kemungkinan sanksi hukum yakni gishash (hukum mati untuk kasus pembunuhan) atau konpensasi material yang disebut dengan diyat. Sedang untuk jenis kedua diancam dengan tiga jenis hukuman -sesuai dengan status pelakunya- yakni rajam, cambuk dan pengasingan. Untuk tindak pidana jenis ketiga dengan qualifikasi tertentu diancam hukuman potong tangan dan untuk tindak pidana jenis keempat diancam dengan hukuman dera delapan puluh kali.20

Dalam hukum Islam tindak pidana yang banyak porsi pembahasannya adalah tindak pidana pembunuhan. Dalam masalah ini dikenal adanya pembedaan-pembedaan antara pembunuhan sengaja, semi sengaja, alfa dan pembunuhan secara terorganisir di mana ada dalang dan ada pelaku langsung (pelaksana). Di sisi lainnya, hukum Islam juga nampak membedakan antara tindak pembunuhan murni yang dalam sanksi hukumnya disamakan dengan pengrusakan, dengan pembunuhan yang integral. dengan kejahatan atas harta (perampokan). Untuk pembunuhan pertama dikenakan hukuman mati, sedang yang kedua dikenakan hukuman mati dengan salib.

Tindak pidana yang sanksi hukumnya belum definitif disyari'alkan oleh Allah, maka sanksi hukumnya tergantung pada ijtihad pemegang kekuasaan hukum. Termasuk dalam jenis tindak pidana ini adalah semua bentuk tindak pidana di luar tindak pidana di atas seperti tindak pidana mengganggu ketertiban umum atau menyebarkan rasa takut di tengah masyarakat tanpa maksud membunuh, merampas harta atau merusak. Termasuk juga dalam tindak pidana jenis ini adalah tindak pidana pembangkangan terhadap pemerintah. Bentuk sanksi hukum untuk tindak pidana ini dapat berbentuk penjara atau pengasingan. ${ }^{21}$

\section{Simpulan}

Jika berbagai konsep tindak pidana dalam sistem hukum Islam ini akan digunakan untuk membidik tindak pidana teror, maka dapat dilihat bahwa baik karakter pidananya maupun sanksi hukumnya sudah tersedia dalam sistem hukum Islam. Hanya saja secara umum konsep hukum Islam dirancang sebagian besarnya pada era yang jauh terlebih dahulu dibanding dengan munculnya tindak pidana terorisme yang modusnya baru belakangan ini

ro Ibn Rusyd, Bidayatu at-Mujtahid wa Nihayal al-Muqtasid, (Semarang: Usaha Keluarga, tt), hlm. Il:296.

2' Yoseph Schacht, An Introduction to Islamic Law (London: Oxford Unversity Press, 1964), hlm. 187. 
dirancang, tentu ada saja titik perbedaannya. Misalnya hukum Islam lebih banyak bicara tentang tindak pidana biasa yang korbannya rata-rata personal sedang tindak pidana terorisme memakan korban massal. Jadi dalam hal intensitas kriminalnya, tindak pidana terorisme lebih segala-galanya atas tindak pidana yang diatur penyelesaiannya oleh hukum Islam.

Namun demikian, sebagai konsep dasar, nampaknya hukum Islam relatif lebih tepat menjadi basis dari satu konsep hukum yang spesifik menyangkut tindak pidana terorisme. Hal ini dapat disimak dari segi karakter dasar tindak pidana terorisme yang kesemuanya sudah tercover dalam konsep pidana Islam.

Pertama, misalnya karakter pengrusakan atas aset publik, obyek-obyek vital, seperti property, lingkungan hidup atau pusat-pusat budaya, dengan dasar hukum Q.S. 5: 33, "Sesungguhnya balasan orang-orang yang memerangi Allah dan Rasul-Nya dan melakukan pengrusakan di muka bumi adalah dihukum mati (dibunuh), disalib atau dipotong tangan.....". Hukum Islam sudah mendapatkan jawaban atas hukuman apa yang paling tepat untuk tindak pengrusakan yang integral dengan tindak pidana terorisme dimanapun. Walaupun misalnya pelaku kejahatan ini adalah orang Islam, maka demi menegakkan prinsip keadilan, perdamaian dan cinta kasih, pelakunya tetap harus dikenai hukuman sesuai dengan alternatif yang diberikan alQuran.

Kedua, karakter hilangnya banyak nyawa manusia yang integral dalam setiap tindak pidana terorisme, sudah dapat diantisipași oleh hukum Islam dengan hukuman qishash. Tarutlah tindak pidana terorisme dilakukan secara sistemtis terorganisir, maka hukum Islam sudah menyediakan sanksi untuk setiap orang yang terlibat dalam proses aksi pembunuhan baik perancangnya, sutradara maupun pelaku langsungnya, yakni berkisar antara qishash dan diyat serta hilangnya hak waris. ${ }^{22}$

Ketiga karakter dari tindak pidana terorisme, yakni menimbulkan ketakutan. secara luas di masyarakat, oleh hukum Islam juga sudah diantisipasi. Misalnya tindak teror dengan cara memasang bom palsu di tempattempat umum atau menginformasikan akar meledaknya bom di suatu tempat keramia. sehingga menimbulkan kepanikan masyarakat padahal tidak ada bom yang dimaksud. Hanya seprti inipun oleh hukum Islam sudah diberi alternatif sanksi hukum pengasingan bay pelakunya. Karen adalam hal ini pelakunyc. sudah menebarkan rasa takut di masyarakat walau dia tidak punya maksud untuk membunuh sesama atau mengambil harta.

Akan tetapi kasus seperti ini relatif jarang terjadi, karena tersebarnya rasa takut di tengah masyarakat sulit terpisahkan dari dua karakter yang pertama. Karena ini adalah target final yang dikehendaki teroris setelah melakukan pembunuhan atau pengrusakan. Artinya sanksi hukum yang pokok untuk tindak pidana terorisme menurut hukum Islam adalah hukuman mati. Karena ketiga karakter ini niscaya muncul secara simultan dalam setiap tindak pidana terorisme.

${ }^{22}$ Ibid., hlm. 181 


\section{Daftar Pustaka}

Amsyari, Fuad, "Kampanye Terorisme dan Reaksi Umat Islam," makalah Workshop, Yogyakarta: 2003.

Hanafi, Ahmad, MA., Asas-asas Hukum Pidana Islam, Jakarta: Bulan Bintang, 1990.

Ibn Rusd, Bidayatu al-Mujtahid wa Nihayat alMuqtasid, Semarang: Usaha Keluarga, tt.

Lewis, Bernard, The Crisis of Islam, Holy war and in Holy Terror, New York: Modem Library, 2003.

Meyer, Mark Juergens, Teror Atas Nama Tuham Kebangkitan Global Kekerasan Agama, Terj. M. Sadat Ismail, Jakarta:
Mizan Press, cet. 1, 2002.

Schacht, Yoseph, An Introduction to Islamic Law, London: Oxford Unversity Press, 1964.

Supono, Eusta, "Terorisme" dalam Bernas, Kamis 17 Oktober 2002.

Al-Quran al-Karim, Surakarta: 1989.

Undang-undang No. 15 tahun 2003 tentangPemberantasan Tindak. Pidana Terorisme.

http://www.irib.ir/worldservice/melayuRADIO/ perspektiffislam terorisme.

http://mail2.factsoft.de/pipermail/national/ 2002-November/010752. .

\section{0}

